\title{
THE PRINCIPLE OF ADULT EDUCATION (AE) THROUGH THE COMMUNITY EMPOWERMENT IN HOUSEHOLD WASTE MANAGEMENT AT BENING SAGULING FOUNDATION
}

\author{
Indra \\ IKIP Siliwangi \\ indra.darmawan77@gmail.com
}

\begin{abstract}
Adult Education (AE) is the education which is more oriented to realistic application towards what is felt and faced in daily life. Waste problems in modern life have been very crucial concern and issues to be solved. Through the empowerment which puts forward the change of the mindset about waste from a problem into a blessing, establishment of waste management institution, strengthening management capacity through training and mentoring continuously can be one of the solutions in household waste management. The community empowerment in household waste management can increase family's income and conserve the environment, so that the community which is independent economically and sustainable environment can occur.
\end{abstract}

Keywords: Adult Education, Community Empowerment, Waste

\section{A. INTRODUCTION}

The Adult Education (AE) is the education the education which is more oriented to realistic application towards what is felt and faced in daily life. Realities and experiences of adults have enriched knowledge, thus the adults need a treatment which is appreciative, especially in taking a decision. The adults will refuse the learning situation whose conditions contradict their life concepts as an independent person.

The problem of people's lives and dynamics of life are developing steadily from generation to generation. In modern life like nowadays, the world are faced with waste problems and solutions as the effects from lifestyles. According to Jambek, the average people produce $0.6 \mathrm{~kg}$ waste per day, in which $75 \%$ of the waste is organic waste and $25 \%$ is inorganic waste like plastic, metal, and paper.

Indonesia itself is the world second biggest plastic waste contributor after China, which is about 3.32 million tons plastic waste are produced every year, so that it is no wonder if rivers and beaches in big cities like Bali, Bandung, and Jakarta experience waste pollution which is at an alarming stage.

Waste solution which still applies collecting, carrying away, and disposing cannot be applied anymore because in this system, the government's role is really dominant, meanwhile the roles of community and private are less visible. A paradigm shift of waste solutions in which the waste is not useless junk which needs to be got rid of or thrown away by government is needed. The contribution of community in waste management is needed by education approach and community empowerment, in which 
in this process, the community is directed to be more powerful and capable of independently processing waste in their homes.

Based on the explanation above, therefore the researcher thinks that Adult Education (AE ) in empowering community through waste management can have positive impact on environmental conservation. Thus, the researcher wants to study in order to find the truth about how the impact of adults' principle in empowering the community towards household waste management is.

\section{B. THEORETICAL FRAMEWORK}

According to UNESCO (Townsend Coles, 1977), the Adult Education (AE) is the whole process of education which is organized, whatever the content, level, or method is, both formal and informal, which continues and replaces the former education in schools, academies and universities as well as work-training, which makes people considered mature by the community developing their abilities, enriching their knowledge, improving their technical or professional qualifications, and resulting in changes in attitudes and behavior in the perspective of dual overall personal development and participation in balanced and free social, economic and cultural development. The above definition emphasizes the achievement of individual development and the increasing of social participation.

According to Suprijanto (2007), adult education has 10 principles which can create an effective and efficient learning- atmosphere. Those 10 principles are; (1). Partnership (2). Real experience (3). Togetherness (4). Participation (5). Self-Reliance (6). Sustainability (7). Benefits (8). Readiness (9). Locality (10). Integration.

Based on law no. 18 of 2008 about waste management, waste management is defined as a systematic, comprehensive, and continuous activity which includes waste reduction and waste management. Waste management cannot be solved only by the government by "collecting, carrying away, disposing" to the landfill, but it must be done comprehensively and integrated from upstream to downstream to provide economic benefits, health for the community and safety for the environment, and can change people's behavior.

Effective waste management is at its source or household-based, in which waste starts to be sorted and processed at home. The role of family education is very instrumental and very strategic in helping to improve the environment, starting from the family as the smallest environment to be accustomed to sort and process waste from the source.

The involvement of the community in waste management with an approach to adult education through empowerment is very much in line with law no. 18 of 2008, that people must actively participate in managing waste at the source with the 3R approach, which are reduce, reuse and recycle. According to Damanhuri (2010) sorting activities and recycling are done as much as possible from the waste collection to the final waste disposal. The operational technique of urban waste management which consists of storage activities to the final disposal of waste must be integrated by sorting from the source. Community involvement in waste management can be done through awareness, 
mentoring and empowerment, in which in this process the community is directed to become more powerful and able to process waste from the sources, so that waste is no longer considered a burden but an asset which can provide added value to empower the community.

Slamet (2003) explains in more detail that what is meant by empowered people are people who know, understand, get motivated, have opportunities, take advantage of opportunities, have energy, are capable to work together, know various alternatives, are able to make decisions, are willing to take risks, are able to find and get information, and able to act in line with the situation. The empowered process which creates the community whose behaviors are expected must be done continuously by optimizing the participation of the community in a responsible way.

\section{RESEARCH METHODS}

The research method used in this research is descriptive method, which is used to depict the attempt which has been done by Bening Saguling foundation at Kabupaten Bandung Barat in managing household waste by using the adult education (AE) approach and the community empowerment.

\section{DISCUSSION}

Law no. 18 of 2008 states that waste is no longer dominated by the government, but the responsibility of all parties, including the community, integrated waste management must start from home as a source of waste. Therefore, the role of public education related to waste management is very important, so that the waste problem will no longer be the main problem which pollutes the environment, especially rivers and seas.

The public education approach which is actualized through the community empowerment can be an alternative solution, where waste is no longer seen as useless waste material and becomes a burden, but waste is positioned to be an asset that has economic, social, and environmental values that if it is managed can increase the level of community life.

According to Law No. 18 of 2008, waste management with community participation is oriented through reduce, reuse, and recycle, so that waste disposed in the landfill is only a residue that has no economic value.

Meanwhile for the organic waste, the community can use it as compost or organic fertilizer with simple composter tools, Takakura basket, vermicompost, biopore, and biodigester, in which organic waste becomes energy by utilizing methane gas into biogas.

The approach of adult education (AE) which has empowerment, usefulness, partnership, sustainability principles in waste management can be actualized through several stages including:

1. Changing Mindset

Adult Education (AE) in waste management is started from the socialization of waste, where the community needs to be given an understanding of the concept of waste and changes the way they think from waste is economic and environmental 
burdens to assets which can generate benefits in terms of economic, environmental and social. The sorted organic waste can be processed into fertilizer, biogas and can increase family income and reduce stacks in the landfill, while inorganic waste such as plastic and metal can be recycled into various new products and add additional income for the family.

2. The Establishment of Institutional Waste Management

After there is a change in the way people think about waste, the next step is to strengthen the community's contribution in waste management, by establishing of community institutions in waste management, the institutional form of waste management can be various, it can be in the form of waste cooperative institutions, waste bank or waste management institutions. The institution of waste management is intended to coordinate the waste management from households at the community level, RT, RW, or village, so that the waste problem can be completed at the community level while the residue in the form of new non-recyclable waste is sent to the final disposal site. Thus, there will be a reduction of waste volume which is disposed directly to the landfill; thereby it reduces the cost burden that must be incurred by the government. The formation of waste management institutions will also strengthen waste management in the regional level, the existence of waste management institutions will increase community participation and welfare at the RT, RW, or village level, where there will be a velocity of money in the form of management services, waste utilization results, and most importantly health quality improvement and clean environment.

3. Management Training and Waste Sorting Techniques

Management training and waste sorting techniques are parts of public education in managing household waste, where people need to know the waste sorting techniques, both organic and inorganic waste. With an increase of knowledge waste sorting techniques and management, it will affect the quality of sorted waste and it will increase the waste value to be processed at the next stage.

4. Market Access

One of the obstacles faced by waste management business doers is market access that is still closed for them, so that the strengthening community empowerment in waste management must be directed to strengthen the market access for them, with more open market access, it will shorten distribution tracks, so that the selling value waste that will be recycled will also increase.

5. Continuous Assistance

The most important thing in public education is continuity and usefulness, in which in empowering the community through waste management in the household, it is necessary to be accompanied, facilitated, and directed to the empowered stage. Indicators of empowered communities include being able to work together, having motivation, being able to take advantage of opportunities and being sustainable. Community assistance in managing household waste can be done by nongovernmental organizations, private, and government. The role of the government in community assistance is very strategic; this is in accordance with Law No. 18 of 
2008 that the task of the government is to coordinate all the potencies in waste management.

\section{E. CONCLUSION}

Adult Education is oriented to real daily needs which are developed in the midst of society, where adult education which has the principle of partnership, empowerment, and benefits are in line with the principle of community empowerment.

Waste problems become environmental issues which are developed and need a comprehensive solution, where garbage is no longer the responsibility of the government, but all parties including the community. Through household-based garbage procession where waste sorting and processing which is done in its source is no longer just a waste transport gathering, it will increase the age of the landfill.

Adult education is actualized through socialization and mindset changes, the establishment of waste management institutions and waste sorting techniques will increase the productivity and effectiveness of the community in household-based waste management.

Through adult education which is actualized in community empowerment in managing household waste, it will create an independent and sustainable environment.

\section{REFERENCES}

Ardiwinata, J. S., \& Mulyono, D. (2018). Community Education in the development of The Community. Empowerment, 7(1), 25-35.

Damanhuri, E. dan Padmi, T. (2011) Teknologi Pengelolaan Sampah, Bandung: ITB

Enceng Mulyana (2012) Model tukar belajar ( Learning Exschange) dalam prespektif pendidikan luar sekolah

Hasan S. Engking (2008) Penuntun penentuan proposal penelitian dan penulisan skripsi. STKIP Siliwangi Bandung

Jamasy, 0. (2004) Keadilan, Pemberdayaan, \& Penanggulangan Kemiskinan. Jakarta Selatan: Blantika.

Kartasasmita, G. (1996) Power and Empowermant: Sebuah Telaah Mengenal Konsep Pemberdayaan Masyarakat. Jakarta: Badan Perencanaan Pembangunan Nasional.

Pranarka (ed). (1996). Pemberdayaan: Konsep, Kebijakan dan Implementasi. Jakarta: Center for Strategic and Inter-national Studies (CSIS).

Simon, H. (1993) Hutan Jati dan Kemakmuran. Problematika dan Strategi Pemecahannya. Yogyakarta: Aditya Media.

Slamet, M. (2003) Pemberdayaan Masyarakat. dalam Membetuk Pola Perilaku Manusia Pembangunan. Disunting oleh Ida Yus- tina dan Adjat Sudradjat. Bogor: IPB Press.

Sujana,D. (2000) Managemen program pendidikan non formal dan pengembangan sumberdaya manusia 